\title{
Population biology and color patterns of the blue land crab, Cardisoma guanhumi (Latreille 1828) (Crustacea: Gecarcinidae) in the Northeastern Brazil
}

\author{
Silva, CC. ${ }^{a, b *}$, Schwamborn, . $^{c}$ and Lins Oliveira, JE. ${ }^{b}$ \\ aPrograma de Pós-graduação em Biologia Animal, Universidade Federal de Pernambuco - UFPE, \\ Av. Professor Moraes Rêgo, 1235, Cidade Universitária, CEP 50670-420, Recife, PE, Brazil \\ bLaboratório de Biologia Pesqueira, Departamento de Oceanografia e Limnologia, Universidade Federal do \\ Rio Grande do Norte - UFRN, Av. Via Costeira, s/n, Praia de Mãe Luíza, CEP 59014-000, Natal, RN, Brazil \\ 'Departamento de Zoologia, Universidade Federal de Pernambuco - UFPE, Av. Professor Moraes Rêgo, \\ 1235, Cidade Universitária, CEP 50670-420, Recife, PE, Brazil \\ *e-mail:cylenecamara@yahoo.com.br
}

Received: March 11, 2013 - Accepted: July 07, 2013 - Distributed: December 31, 2014

(With 5 figures)

\begin{abstract}
The objective of this study was to analyze the population biology and color patterns of Cardisoma guanhumi Latreille, 1828 in a mangrove area in Natal, Rio Grande do Norte, Brazil. Crabs were collected monthly between February 2010 and January 2012 and totaled 1,837 individuals. Sex ratios were similar between males and females in the first year and differed in the second. Sex ratios by size class differed statistically in the extremes of the distribution, with an abundance of males in the large size classes. There was no difference $(p>0.05)$ in carapace width between males and females in the first year, but in the second year, males were larger than females $(p=0.003)$, showing the importance of considering interannual variation in such studies. Both sexes presented a unimodal distribution. The size of first maturing of the females was $6.00 \mathrm{~cm}$. Asymptotic carapace width for males was $9.4 \mathrm{~cm}$ and females for $9.2 \mathrm{~cm}$, using the Wetherall method. There was no defined modal progression, which made the determination of the Von Bertalanffy growth parameter $\mathrm{K}$ impossible. Juveniles were found throughout all months of the year, demonstrating that there was no defined period of recruiting, although slightly fewer juveniles were found in the dry season. Four color patterns were observed, the three first patterns were the same for both sexes, while the fourth pattern was observed in females only. The four color patterns identified could be clearly related to the stage of development (size) and sexual maturity of the animal.
\end{abstract}

Keywords: blue land crab, colour pattern, sex ratio, size frequency distribution.

\section{Biologia Populacional e padrões de coloração do caranguejo terrestre, Cardisoma guanhumi (Latreille 1828) (Crustacea: Gecarcinidae) no Nordeste do Brasil}

\begin{abstract}
Resumo
O objetivo deste artigo foi analisar a biologia populacional e os padrões de coloração da carapaça de Cardisoma guanhumi Latreille, 1828 em uma área de manguezal em Natal, Rio Grande do Norte, Brasil. Os caranguejos foram coletados mensalmente entre fevereiro de 2010 e janeiro de 2012 e totalizaram 1837 caranguejos. A proporção sexual foi semelhante para machos e fêmeas (1:1) no primeiro ano e diferiu no segundo ano. A proporção sexual por classe de tamanho diferiu estatisticamente nas classes extremas da distribuição, com abundância de machos nas superiores. Não houve diferença $(p \geq 0,05)$ entre as larguras de carapaça de machos e fêmeas no primeiro ano, porém no segundo os machos foram maiores que as fêmeas $(\mathrm{p}=0,003)$, revelando à importância de se considerar as variações interanuais nestes estudos. Ambos os sexos apresentaram distribuição unimodal. $\mathrm{O}$ tamanho de primeira maturação sexual das fêmeas foi $6,00 \mathrm{~cm}$. A largura de carapaça assintótica para machos foi de $9,4 \mathrm{~cm}$ e para as fêmeas de $9,2 \mathrm{~cm}$, usando o método Wetherall. Não houve progressão modal definida, o que impossibilitou a determinação do parâmetro de crescimento k de Von Bertalanffy. Foram encontrados juvenis ao longo de todos os meses do ano, mostrando não haver um período de recrutamento definido, embora a abundância de juvenis tenha sido menor na estação seca. Foram observados quatro padrões de coloração, três para ambos os sexos e um quarto padrão observado apenas para as fêmeas. Os quatro padrões de coloração da carapaça estão claramente relacionados ao estágio de desenvolvimento (tamanho) e à maturidade sexual do animal.
\end{abstract}

Palavras-chave: guaiamum, padrão de coloração, proporção sexual, distribuição de tamanho. 


\section{Introduction}

The blue land crab Cardisoma guanhumi (Latreille, 1828) displays a wide distribution in the West Atlantic, ranging from Florida (U.S.) to Santa Catarina, southern Brazil (Burggren and McMahon, 1988; Branco, 1991). As a semi-terrestrial species, even though most of its life cycle is in a terrestrial environment, where it feeds and reproduces, it depends on the aquatic environment for dispersion and planktonic larval development (Bliss, 1979; Burggren and McMahon, 1988). This species builds its galleries above the line of the high tide (Melo, 1996) in the upper mangrove fringe and in areas adjacent to mangroves (Schaeffer-Novelli, 1989). It is an important socio-economic resource in many countries in Latin America and in the Caribbean (Feliciano, 1962; Taissoun, 1974; Wolcott, 1988; Rodriguez-Fourquet and Sabat, 2009).

In Brazil, this species is a highly valued resource, especially in the coastal region of Northeastern Brazil, and is frequently sold at indoor and outdoor markets or roadside stands near mangrove areas, being a favorite ingredient in the regional cuisine (Oshiro et al., 1999; Botelho et al., 2001). This demand for consumption has generated a strong pressure on crab populations, and is one of the contributing factors of the significant decrease in stock size observed in Northeastern Brazil (Botelho et al., 2001). Besides the increase in consumption, the species also suffers from impacts caused by the changes generated by direct or indirect devastation of their habitat, where the vegetation of the mangrove is destroyed to provide space, primarily for the expansion of ports, industries, salt production and shrimp farms (Vannucci, 1999; Duarte et al., 2008).

Studies on C. guanhumi are extremely important, since there is an enormous lack of information, especially in northeastern Brazil (Abrunhosa et al., 2000; Botelho et al., 2001; Shinozaki-Mendes et al., 2008; Shinozaki-Mendes et al., $2012 \mathrm{a}, \mathrm{b})$ related to the population biology; this information is essential for the proper management of this resource, to allow sustainable exploitation of the species, as its populations are already being overexploited (De Oliveira-Neto et al., 2008; Firmo et al., 2012; Shinozaki-Mendes et al., 2012a).

The lack of information about the species C. guanhumi is also reflected by the number of studies dedicated to classifying and quantitatively investigating the relationship of the carapace color patterns: there are just two published studies (Gifford, 1962; Silva and Oshiro, 2002). In semiterrestrial crabs, the color patterns are correlated to variations in behavior and physiology (Reid et al., 1997; Silbiger and Munguia, 2008).

Thus, the objective of this study was to describe the population structure of this species in a mangrove area with restricted access in the state of Rio Grande do Norte, with regard to sex ratio, size frequency distribution, relative abundance of juveniles, growth and color patterns. The choice of a mangrove area with restricted access and negligible fishing mortality was essential to avoid any effects of fishing selectivity for size, sex or color.
The following hypotheses are tested: (a) the sex ratio differs according to size class, (b) carapace width and growth differs between sexes and between the periods studied, (c) there is a distinct seasonal recruitment period, and (d) the distinct color patterns are related to size, sex and stage of maturation.

\section{Material and Methods}

Samples of C. guanhumi were collected, without the reposition of the individuals, in a monthly interval over two years, from February 2010 to January 2012. The sampling area is located in the lower estuary of the Potengi river ( $5^{\circ} 47^{\prime} 22,8^{\prime}$ 'S $\left., 35^{\circ} 13^{\prime} 10,5^{\prime \prime} \mathrm{W}\right)$, in a mangrove area of the Naval Base of the city of Natal, Rio Grande do Norte State, located in northeastern Brazil; thus, this is inside a military area with restricted access and negligible capture of land crabs.

The specimens were collected using cylindrical traps with diameters of $40 \mathrm{~mm}$ (120 mm long) and $100 \mathrm{~mm}$ (250 $\mathrm{mm}$ long). The traps were set up in all burrows occupied by crabs, determined by the presence of feces in the entrance of the burrow. Sampling was initiated at 9 am and stretched until $5 \mathrm{pm}$, with harvest intervals of 1 and a half hours; where crabs were trapped, they were harvested and the traps were armed again.

In the lab, the following parameters were determined: sex, color and width of the carapace $(\mathrm{CW})$. The individuals were classified as Juvenile (A - immature) or adults ( $\mathrm{B}, \mathrm{C}, \mathrm{D}$ and $\mathrm{E}$ - mature), through a macroscopic analysis of the stages of gonad development (Botelho et al., 2001), based on its shape, size, consistence and coloration. This species presents three color patterns for males and four for females (Silva and Oshiro, 2002). The patterns are classified as follows: pattern 1 - characteristic for the juvenile stage, when the dorsal part of the carapace is a yellowish brown and the sides are a light purple, the chelipeds and legs also have an orange or yellowish brown color; pattern 2 - corresponds to the transition stage, when the animals' body has an intense bluish dark purple tone; pattern 3 - represents the individuals with color of the carapace, chelipeds and legs lavender blue; pattern 4 - is characterized by the whitish, yellowish or grayish color. This pattern is frequently found in adult females; according to Gifford (1962) and Fischer et al. (1978), it is due to ovulation, and can also be observed in the male reproductive period, although rarely.

In the analysis of the sex ratio in each class of carapace width, the test utilized was the chi-square test $\chi^{2}(\alpha=0.05)$; to assess the differences in carapace width between the sexes in the two years analyzed, the $t$ test was used (Zar, 1999). The premises of normality and homogeneity of variances having been tested previously. In classes where the values of $n$ (number of individuals) were less than 20 and the expected frequencies were less than 5, we used the Fisher's Exact Test (Beiguelman, 1994).

The relative frequency (\%) of the adult females in each size class was plotted in a graph in which a sigmoid 
curve was adjusted, following the results of the logistic equation $\mathrm{y}=1 /\left(1+\exp \left[-\mathrm{r}\left(\mathrm{CW}_{1}-\mathrm{CW}_{50}\right)\right]\right)$, where $\mathrm{CW}_{1}$ is the upper limit of the length class, $\mathrm{CW}_{50}$ is the width of the carapace at which $50 \%$ of the individuals reach sexual maturity and $r$ is the slope of curve. The adjustment of the equation was performed through minimum squares (Vazzoler, 1996).

For the adjustment of the Von Bertalanffy growth curve, the ELEFAN routine was used (Pauly and David, 1981), as incorporated in the FISAT II program (Gayanilo et al., 1996; Gayanilo and Pauly, 1997). The asymptotic CW $\left(\mathrm{CW}_{\text {inf }}\right)$ was estimated using the Wetherall plot routine (Wetherall, 1986; Pauly, 1986; Wetherall et al., 1987), which is a method that has proven extremely robust to estimate asymptotic length, even when there is no clear modal progression (Palomares and Pauly, 2009).

To verify whether there is a significant difference in the abundance of juveniles throughout the months in the two years analyzed, the chi-square $\left(\chi^{2}\right)$ was utilized with corrections of Yates and alpha $(\alpha)$ and with a Bonferroni correction (Zar, 1999). This correction consists of adjusting the value of $\alpha$ to $\alpha / \mathrm{n}$, where $\mathrm{n}$ is the number of possible combinations of averages between the pairs. In months where the values of $\mathrm{n}$ (number of individuals) were less than 20 and the expected frequencies were less than 5, we used the Fisher Exact Test (Beiguelman, 1994).

A Kruskal-Wallis ANOVA was used to analyze whether the color pattern reflects significant differences $(\alpha=0.05)$ in the size of the juveniles and adults of males and females, since a priori tests of normality (Kolmogorov and Smirnov test) and homogeneity of variances (Bartlett test) rejected the hypotheses of normality and homogeneity. When significant effects were detected in the Kruskal-Wallis ANOVA, Dunn tests were applied a posteriori to the results (Zar, 1999).

\section{Results}

\subsection{Sex ratio}

A total of 1,837 individuals were captured, with 959 in the first year (477 males and 482 females), with a sex ratio not differing significantly from $1: 1\left(\chi^{2}=0.026\right.$, $\mathrm{p}=0.871)$. In the second year, a total of 878 individuals were captured (472 males and 406 females), with a sex ratio differing significantly $\left(\chi^{2}=4.961, p=0.025\right)$. The sex ratio by size classes was $1: 1(\mathrm{p}>0.05)$ in the intermediary classes, with a larger number of males in the extreme classes of the distribution (juveniles and large adults) for both years (Figure 1).

\subsection{Size distribution}

The size frequency distributions for males and females presented in Figure 2 show a single modal pattern for both sexes in both periods. In the first year, males varied from 1.7 to $8.6 \mathrm{~cm} \mathrm{CW}(5.73 \pm 0.99)$, and females varied from 1.7 to $8.0 \mathrm{~cm} \mathrm{CW}(5.63 \pm 1.00)$. In the second year, males varied from 1.3 to $8.5 \mathrm{~cm} \mathrm{CW}(5.94 \pm 1.10)$ and females from 2.1 to $8.0 \mathrm{~cm} \mathrm{CW}(5.74 \pm 0.92)$. The modal class for

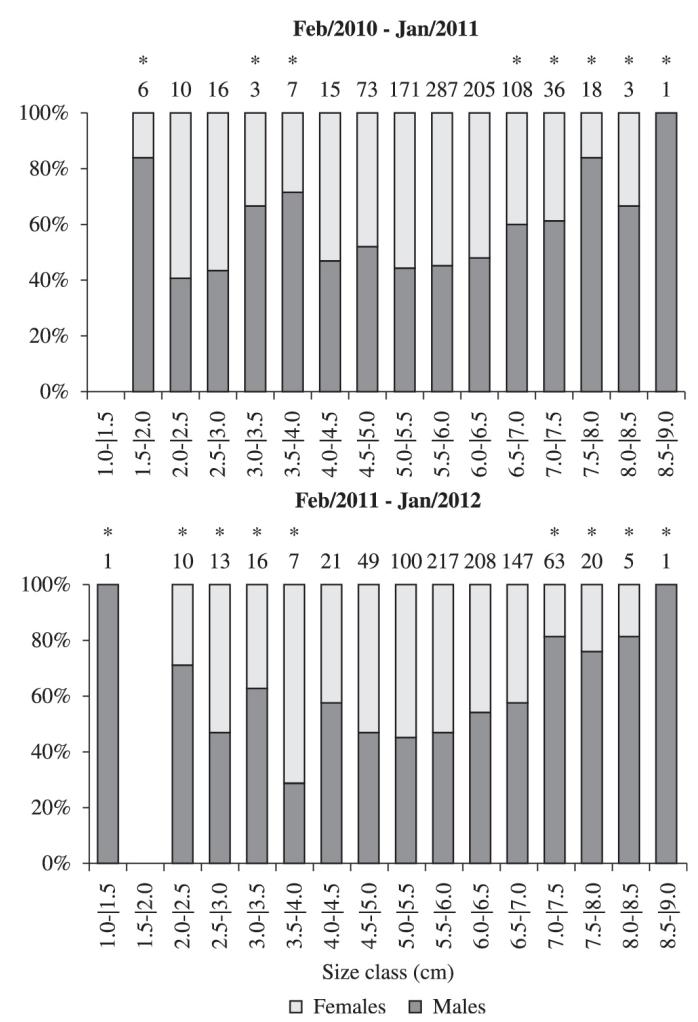

Figure 1. Sex ratio of males and females of Cardisoma guanhumi by size class, sampled in the mangrove of the Potengi River, Brazil, from February 2010 to January 2012. *indicates statistical significance. $\mathrm{CW}$ : carapace width.
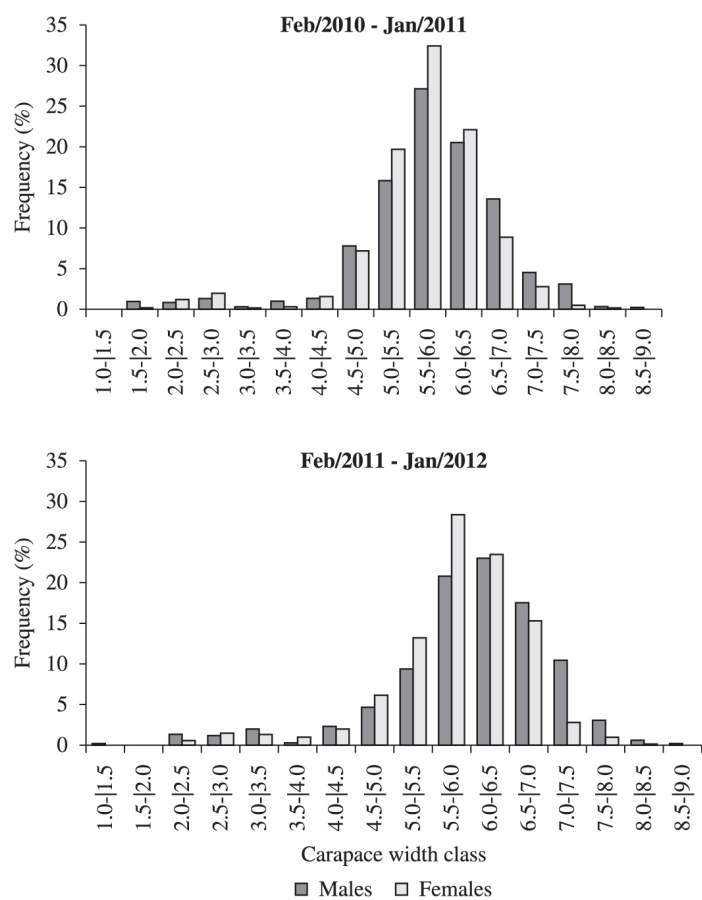

Figure 2. Histogram of size frequency of males and females of Cardisoma guanhumi sampled in the mangrove of the Potengi River, from February 2010 to January 2012. 
both sexes in the first year was $5.5-6.0 \mathrm{~cm} \mathrm{CW}$, but the modal classes were different in the second year: for males it was 6.0-6.5 and for females 5.5-6.0 cm CW. Thus, males were larger than females in the second year, as confirmed by student t-tests. There was no significant difference in $\mathrm{CW}$ between males and females ( $t$-test, $p=0.076$ ) in the first year, but a significant difference between sexes occurred in the second year (t-test, $p=0.003$ ). For females, there was no difference between both years (t-test, $p=0.069$ ), whereas males were significantly larger in the second year (t-test, $\mathrm{p}=0.002$ ).

The size frequency distribution showed that females in general were more abundant until the central size class of 6.0-6.5 cm, while males were more abundant in the larger size classes, starting from the class of $6.5-7.0 \mathrm{~cm} \mathrm{CW}$, in both periods. This fact puts in evidence the predominance of males in the larger size classes in both years and in the smaller size classes in the first year. When comparing the size distributions between years, a decrease in the relative amount of small males and an absolute increase in large males in the second year are thus the main features.

The size at which $50 \%$ of females are mature $\left(\mathrm{CW}_{50}\right)$ was $6.00 \mathrm{~cm} \mathrm{CW}$. The adult females were grouped for both years, as there was no difference in carapace width between years for females.

The monthly size-frequency distributions did not present any modal progression, which made the adjustment of a growth curve and the determination of the growth parameter $\mathrm{K}$ impossible. The values of asymptotic $\mathrm{CW}$ obtained by the Wetherall method were $9.4 \mathrm{~cm}$ for males and $9.2 \mathrm{~cm}$ for females.
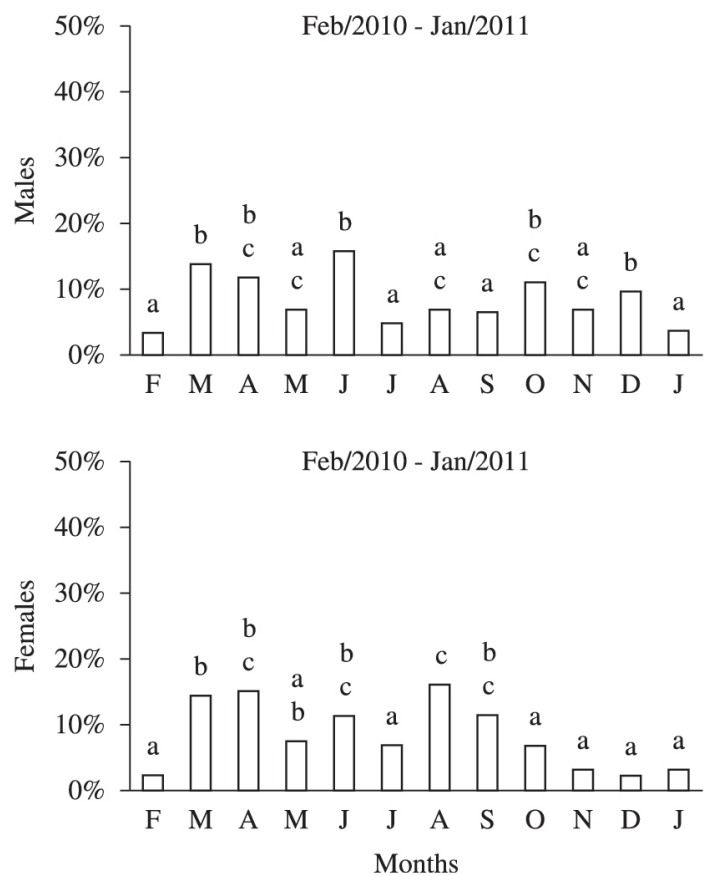

Juveniles were found in every month of the year, with $1-16.3 \%$ of the total individuals caught (Figure 3). For males, there were $2.2-15.8 \%$ juveniles (average: $8.3 \%$ ), while for females, there were $1-16.3 \%$ juveniles (average: $8.4 \%$ ). In the first year, there were 3 groups of relative juvenile abundance $\left(\chi^{2}, p \leq 0.05\right)$ that intermingled throughout the year for males and females. In the second year, there were 4 groups for males and 5 for females that also intermingled throughout the months. A smaller abundance of female juveniles was observed from November to February (i.e. in the dry season) in both periods, indicating a possible increase in recruitment in the rainy season (March-October).

\subsection{Color patterns}

Color patterns were analyzed for 1,502 individuals: 778 males and 724 females. Three color patterns were observed for males and four for females. The three first patterns were the same for both sexes, while the fourth pattern was observed in females only (Figure 4). Pattern 1 was present in males varying from $1.3 \mathrm{~cm}$ to $7.2 \mathrm{~cm} \mathrm{CW}$ and females from $2.1 \mathrm{~cm}$ to $6.6 \mathrm{~cm} \mathrm{CW}$. Pattern 2 occurred in males varying from $1.8 \mathrm{~cm}$ to $7.5 \mathrm{~cm} \mathrm{CW}$ and in females from $2.1 \mathrm{~cm}$ to $7.0 \mathrm{~cm} \mathrm{CW}$. Pattern 3 occurred in males from $1.7 \mathrm{~cm}$ to $8.5 \mathrm{~cm} \mathrm{CW}$ and in females from $2.1 \mathrm{~cm}$ to $8.0 \mathrm{~cm} \mathrm{CW}$. Color pattern 4 occurred only in females, with sizes varying from $5.0 \mathrm{~cm}$ to $7.6 \mathrm{~cm} \mathrm{CW}$.

Considering the maturational stages, both juvenile males and females showed higher abundance in color patterns 1 and 2 (Males - pattern $1=35 \%, 2=52 \%$; Females pattern $1=38 \%, 2=49 \%$ ), whereas adult individuals were more abundant in patterns 2 and 3 (Males - pattern
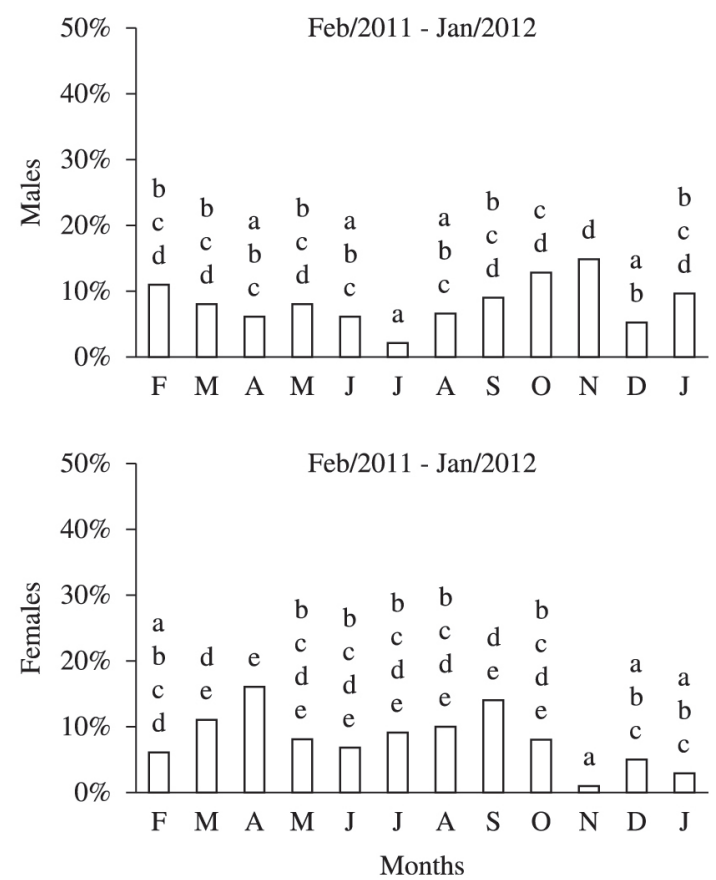

Figure 3. Monthly distribution of the percentage of male and female juveniles of Cardisoma guanhumi sampled in the mangrove of the Potengi River, from February 2010 to January 2012. The letters above the bars correspond to groups according to their abundance, as defined by $\chi^{2}$ tests. 
$2=36 \%$, pattern $3=54 \%$; Females - pattern $2=40 \%$, pattern $3=36 \%$ ).

The results of the Kruskal-Wallis ANOVA to test the differences of average sizes of individuals among the color patterns of C. guanhumi show that (Figure 5), in relation to the size of juvenile males, the color patterns 1 was different from others $(H=24.644 ; p=0.000)$. For adult males, differences in size occurred between all color patterns $(\mathrm{H}=$ 87.475; $\mathrm{p}=0.000)$. Juvenile females presented differences between color patterns 1 and $3(\mathrm{H}=9.802 \mathrm{p}=0.020)$. Adult females did not present any differences between color patterns 3 and 4, but there were differences among these patterns and the others $(\mathrm{H}=105.001 ; \mathrm{p}=0.000)$.

\section{Discussion}

\subsection{Sex ratio}

The present study adds important information in respect to the population biology and color patterns of C. guanhumi, as these data are scarce in the literature, thus hampering the evaluation of the current situation of this extremely vulnerable species.

In relation to the results of sex ratio, the Fischer theory (Fisher, 1930) suggests a sex ratio of 1:1 (female:male). However, some populations may differ from this ratio due to the sex preference for different habitats, mortality, differential growth between sexes and migration (Berglund,
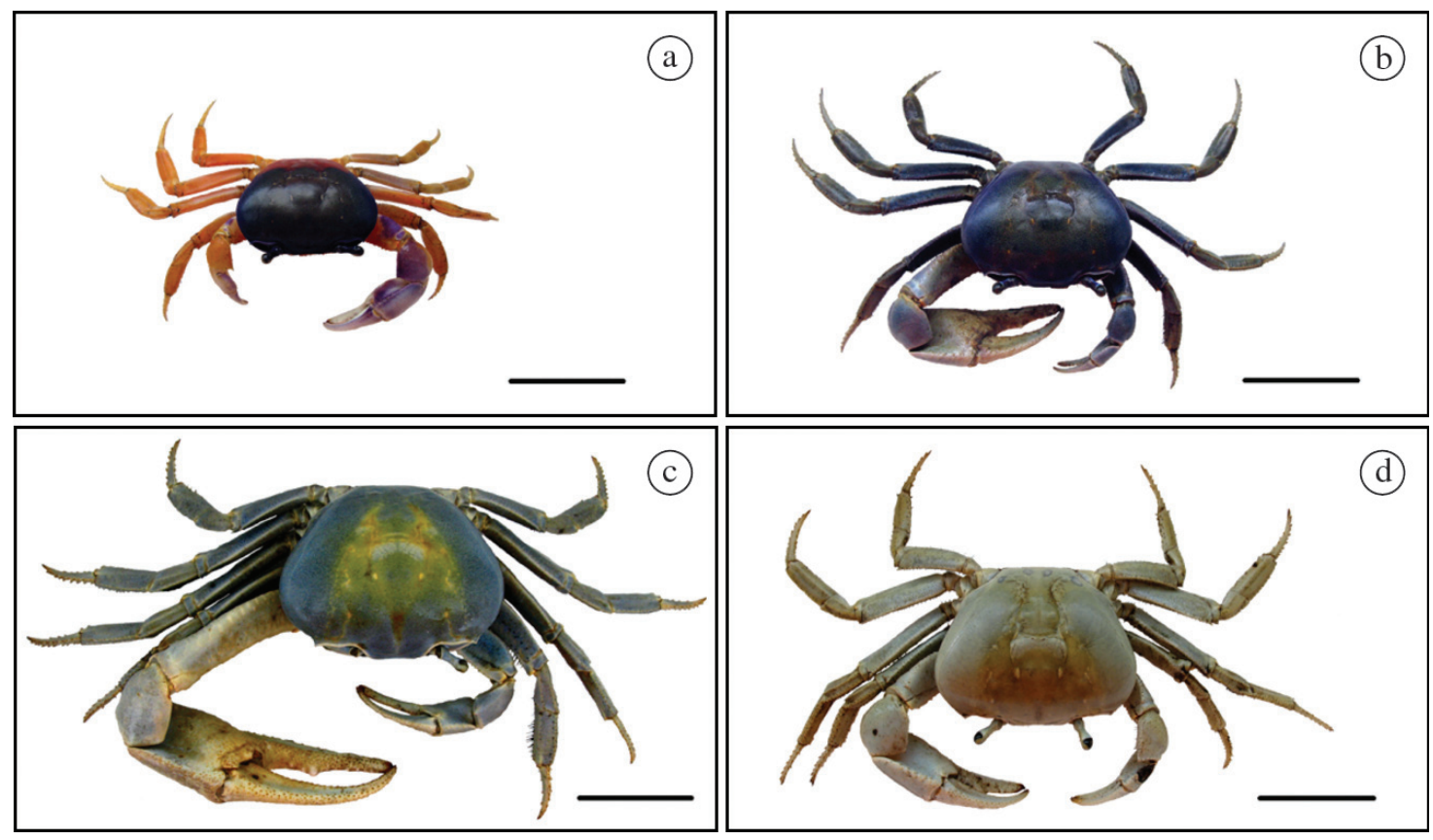

Figure 4. Color patterns of Cardisoma guanhumi collected in the mangrove of the Potengi River, Brazil, from February 2010 to January 2012. a: pattern 1, b: pattern 2, c: pattern 3, d: pattern 4. Scale: $5 \mathrm{~cm}$.

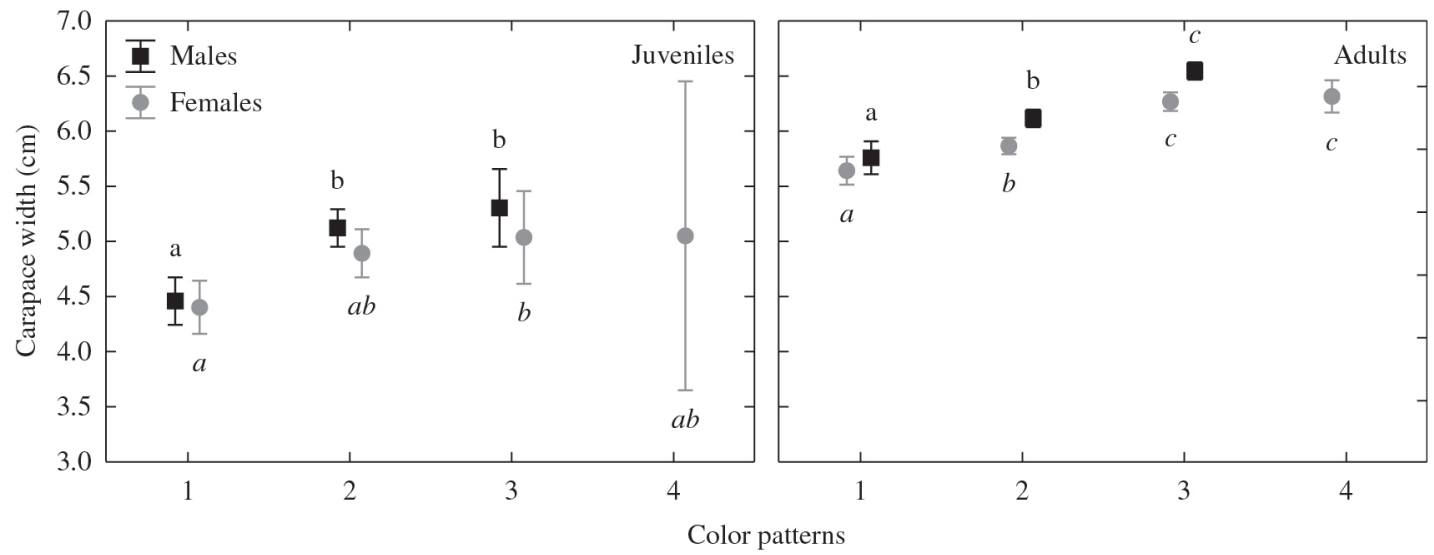

Figure 5. Box plot of carapace width in the different color patterns for males and females of C. guanhumi collected in the mangrove of the Potengi River, Brazil, from February 2010 to January 2012. Box-plots show median and standard error (males $=$ normal letters; females $=$ italic letters; different letters indicate significant differences between the color patterns). 
1981; Johnson, 2003; Diele et al., 2005; Hartnoll, 2006, 2009).

In the present study, sex ratio did not differ from unity in the first year, while in the second year, there was an excess of males, or more specifically, of large males. In other studies conducted for this species, sex ratios did not differ from unity (Figure 1). The smaller abundance of females in the classes of greater size of the distribution can be explained by the greater allocation of energy in the females for reproductive tissues, as well as the dietary restriction during the period of incubation of the eggs, which compromises the somatic growth of females (Alunno-Bruscia and Sainte Marie, 1998; Hartnoll, 2006).

The results show that females were more abundant in the classes up to 5.5-6.0 $\mathrm{cm}$ and the $\mathrm{CW}_{50}$ of the females was $6.0 \mathrm{~cm}$ of carapace width. Therefore, in this size class, $50 \%$ of the females start investing a large amount of their energy in gonad development, which results in a decrease in their body growth, explaining the greater abundance of males in the larger size classes. However, according to Wenner (1972), the ratios in small size classes should be equal, which did not happen in this study, probably due to the selectivity of the capture method, which made it difficult to capture a more abundant amount of individuals in the initial classes of distribution, or possibly, a more active behavior of small males, making them more prone to capture.

\subsection{Size distribution}

A unimodal annualized size distribution for males and females is common for decapods of tropical regions (Warner, 1967; Diaz and Conde, 1989). Gifford (1962), Taissoun (1974) and Henning (1975) propose that the females of this species may spawn up to five times per year, which explains the continuous recruitment, as the females are capable of storing and maintaining the sperm in their spermathecae for years (Taissoun, 1974). In the present study, females were observed with fertilized eggs attached to pleopods and whose gonads were already mature again, indicating at least two sequential ovipositions.

Multiple consecutive ovipositions during a reproductive cycle may explain the impossibility to adjust the von Bertalanffy equation on the length-frequency data. Since recruitment is continuous and without distinct, simultaneously recruiting and growing size classes (i.e. cohorts) throughout the year, it was not possible to observe the presence of cohorts over the months. However, a relevant factor for the inability to adjust the growth curve was the selectivity of the traps that led to a low capture of small juveniles. This is a recurring problem in studies with C. guanhumi, since the capture of juveniles is quite difficult due to the cryptic and agonistic behavior of this species (Hill, 2001; Wedes, 2004). On the other hand, the lack of modal progression may also be an indication of slow growth (low " $\mathrm{K}$ " value) of the species, which has been observed for C. guanhumi. According to Henning (1975), this species is characterized by its slow growth and great longevity compared to other crabs; while other crabs need approximately 20 molts to reach maximum size, C. guanhumi needs up to 60 molts, reaching up to 13 years of age. The slow growth, especially in species affected by overfishing, becomes more of an aggravating factor for the recovery of stocks.

There are few published studies focusing on the population biology of the species C. guanhumi in Brazil (Botelho et al., 2001; Silva and Oshiro 2002; Botelho et al., 2009; Shinozaki-Mendes et al., 2012a, b) and these show that the species reaches larger amplitudes and medium size in Southeastern regions of Brazil. The largest size for the species in the Southeastern region is given because the species is not as appreciated in the regional cuisine in this region and because of factors related to the lower temperature and higher food availability, which act on the population structure of crustaceans (Hartnoll, 1982; Bond-Buckup and Buckup, 1989; Müller et al., 1999; Fischer et al., 2009a, b). This difference can be evidenced in the minimum catch sizes for the species in the regions of Brazil: in the tropical Northeast, except for the state of Bahia, this species has a minimum catch size of $6 \mathrm{~cm} \mathrm{CW}$, but in the cooler Southeast it is $8 \mathrm{~cm} \mathrm{CW} \mathrm{(Brasil,} \mathrm{2003).}$

Botelho et al. (2001) estimated the von Bertalanffy growth parameters of $C$. guanhumi in a population and made caveats to the problems associated to this estimation. They estimated $\mathrm{CW}_{\text {inf }}$ as $8.3 \mathrm{~cm}, \mathrm{~K}$ as 0.594 , and first maturity of the females as 1.47 years. Conversely, Henning (1975) estimated a considerably later first maturity of females as 3.75 years, based on molts in the laboratory. Both estimates may be biased, since a recent study using transponder tags in a related tropical land crab (Ucides cordatus) in northern Brazil (Diele and Koch, 2010) showed that length frequency analysis strangely overestimates growth rates, with drastic consequences for stock assessment.

The length at first sexual maturity of the females of C. guanhumi was $6.00 \mathrm{~cm} \mathrm{CW}$ in the present study; in other words, this was the same size suggested by the Brazilian environmental legislation as the minimum capture size (Shinozaki-Mendes et al., 2012a). However, we herein present the caveat that the sampling site is a restricted access area, where the species is scarcely captured. Compared with other projects, in this study the species presented a late maturing of the gonads. Other authors found considerably lower values of $\mathrm{CW}_{50}$ for females, ranging from 3.55 to $5.87 \mathrm{~cm}$ (Gimenez and Acevedo, 1991; Botelho et al., 2001; Silva and Oshiro, 2002; Shinozaki-Mendes, 2008; Gil, 2009). Only Taissoun (1974) found a larger value of $\mathrm{CW}_{50}(7.00 \mathrm{~cm})$ in Venezuela.

Exogenous parameters can interfere with metabolic rates and growth in individual populations of the same species in different regions, originating different sizes for the beginning of the maturation, as observed by Hines (1989) for some crab species of the West Coast of the United States. Other factors may also influence the size at first maturity, such as salinity and the availability of food resources (D'Incao et al., 1993).

Botelho et al. (2001) found a main period of recruitment between May and September (rainy season). In this study, the analysis of juvenile abundance over the two years 
showed that there is no clearly defined recruiting period, except for a slight decrease in female juveniles during the dry season (mainly in the first period). Recruitment in the rainy season has the advantage of a lower desiccation stress during the occupation of higher, less frequently inundated areas by small juveniles (Diele and Koch, 2010).

Despite the formation of some abundance groups that blend together throughout the year as much for males (both period) as for females (second period), we observed the presence of juveniles throughout every month of the year. This result reinforces what other authors (Gifford, 1962; Taissoun, 1974; Henning, 1975) have reported about the reproductive characteristics of this species (already mentioned in this study), which enables this continuous recruitment.

The distribution by size classes showed that the females were more abundant in the modal and intermediary classes, and were less abundant in the peripheral classes. Similarly, Shinozaki-Mendes (2008) also observed that females were more abundant in the modal class and absent in the peripheral classes in a population of C. guanhumi in the state of Ceará, northeastern Brazil. This predominance of one sex in the peripheral classes may indicate different rates or sizes of recruiting and mortality (ShinozakiMendes, 2008).

Males presented greater amplitude of size and were more abundant in the classes of larger size. This difference is generally more pronounced in aquatic brachyurans than in terrestrial or semi-terrestrial ones (Hartnoll, 1982; Gleenson, 1991). However, this has also been reported in various studies with C. guanhumi (Herreid, 1967; Bozada and Chávez, 1986; Silva and Oshiro, 2002; Rivera, 2005; Shinozaki-Mendes et al., 2008; Gil, 2009). In brachyurans, the larger size of males according to several authors (Warner, 1967; Benetti and Negreiros-Fransozo, 2003; Johnson, 2003; Luppi et al., 2004; Litulo, 2005) is the result of a longer period of somatic growth and a larger increase in size during molting.

\subsection{Color patterns}

The color patterns found in this study corroborate the patterns reported for C. guanhumi by other authors (Gifford, 1962; Silva and Oshiro, 2002; Gil, 2009). However, Gil (2009) reports the capture of two males $(9.2$ and $9.3 \mathrm{~cm}$ $\mathrm{CW}$ ) with color pattern 4 , one in the post-molt period and the other in the reproductive stage, which is a rare color pattern for males according to Gifford (1962) and Fischer et al. (1978).

Phenotypic plasticity in color patterns is often observed in marine crabs and could be related to an advantage against predators (Todd et al., 2006; Reuschel and Schubart, 2007). In semi-terrestrial crabs, the color patterns may change with growth, seasonality, the current state of the individual, such as stress, endogenous rhythms and even temperature changes (Silbiger and Munguia, 2008). It may also be related to osmoregulatory and respiratory physiology, response to desiccation, the molt cycle and mating behavior (Reid et al., 1997).
The color patterns of C. guanhumi are determined by different combinations of effects due to the presence of pigments in the carapace and chromatophores of the epidermis (Gifford, 1962). In this species, it is believed that the color patterns are related to the maturity of the animal (Gifford, 1962) or the development stage (Silva and Oshiro, 2002).

The results found here show that the color pattern of the carapace reflects differences in the sizes of juveniles and adults of both sexes. Hence, the color of the carapace is related as much to the developmental stage as to the maturity of the animal, since both factors are directly related.

The population parameters studied here provide important information for the proper management of this species. In Brazil, the species C. guanhumi as well as other species of semi-terrestrial crabs come under intense capture, which causes a reduction in the size and abundance of these individuals (Amaral and Jablonski, 2005). The findings show that reduced fishing activity observed in the analyzed area contributed to the species obtaining similar parameters to the population of southeastern Brazil, including maintaining capture size $\left(\mathrm{CW}_{50}\right)$, which was established in legislation (Brasil, 2003). However, most areas where the species occurs have easy access to fishermen and little or no oversight by government agencies is observed. Thus, factors such as slow growth of the species, indiscriminate capture of individuals who have not yet reached maturity, the capture of females that is prohibited under any circumstances and no respect to the closed period were decisive for this species reaching the level of current vulnerability.

All this factors contributed to the species be classified nowadays how critically endangered (CR) (Subirá et al., 2012).

\section{Conclusion}

The analysis of the sex ratio shows that the percentage of males and females may differ over the years and males tend to be more abundant, especially in the larger size classes. However, despite the fact that the males of C. guanhumi do not differ from the pattern presented for the brachyuran crabs, where males tend to be larger than females, there was no significant difference between the averages of carapace width of males and females in the first year of sampling.

The distribution of the single modal type expected for decapods was confirmed for C. guanhumi. It was not possible to estimate the $\mathrm{K}$ growth parameter, due to characteristics inherent to the species which were reported by other authors, such as slow growth and high longevity, being aggravated by the difficulties in sampling juveniles.

The species does not present a well-defined recruiting period. The color patterns of the carapace are clearly related to the development stage and sexual maturity of the animal.

The present study brings relevant contributions to the study of this species and to the understanding of its biology, besides being the first study to relate color patterns to size 
and gonadal development stages. However, further studies are necessary for a better comprehension of its population biology and the factors related to its color patterns, especially considering its socio-economical importance and its current status of vulnerability to overharvesting.

\section{Acknowledgements}

Our sincere thanks go to Wellington S. Xavier, who assisted in the field work, Aline Alves and Beatriz Nascimento, for their collaboration in sampling, and the Naval Base of Natal for authorizing this study within its facilities. We would also like to thank the Laboratory of Fishing Biology (LABIPE/DOL/UFRN) for all of the logistical support, without which this project would not have taken place. This article is part of the Doctorate Thesis of the first author and was financed by a research grant of the Brazilian National Research Council - CNPq (grant no. 579540/2008-1). This study was realized with the permission of collection (IBAMA no. 18003-2).

\section{References}

AMARAL, ACZ. and JABLONSKI, A., 2005. Conservação da biodiversidade marinha e costeira no Brasil. Megadiversidade, vol. 1 , no. 1 , p. $43-51$

ABRUNHOSA, FA., MENDES, LN., LIMA, TB., YAMAMOTO, SO. and OGAWA, M., 2000. Cultivo do caranguejo terrestre Cardisoma guanhumi (Latreille, 1825) do ovo ao estágio juvenil. Revista Científica de Produção Animal, vol. 2, no. 2, p. 190-197.

ALUNNO-BRUSCIA, N. and SAINTE-MARIE, B., 1998. Abdomen allometry, ovary development, and growth of female snow crab, Chionoecetes opilio (Brachyura, Majidae), in the northwestern Gulf of St Lawrence. Canadian Journal of Fisheries and Aquatic Sciences, vol. 55, no. 2, p. 459-477. http://dx.doi. org/10.1139/f97-241.

BENETTI, AS. and NEGREIROS-FRANSOZO, ML., 2003. Madurez sexual morfológica del cangrejo Uca burgersi, Holthuis, 1967 (Brachyura, Ocypodidae) de uma área de manglar subtropical de Brasil. Universidad y Ciencia, vol. 19, no. 37, p. 9-16.

BERGLUND, A., 1981. Sex dimorphism and skewed sex ratios in the prawn species Palaemon adspersus and P. squilla. Oikos, vol. 36, no. 2, p. 158-162. http://dx.doi.org/10.2307/3544440.

BEIGUELMAN, B., 1994. Curso prático de bioestatística. 3rd ed. Ribeirão Preto: Sociedade Brasileira de Genética. 244 p.

BLISS, DE., 1979. From sea to tree: saga a land crab. American Society Zoologists, vol. 19, p. 385-410.

BOND-BUCKUP, G. and BUCKUP, L., 1989. Os Palaemonidae de águas continentais do Brasil meridional (Crustacea, Decapoda). Revista Brasileira de Biologia = Brazilian Journal of Biology, vol. 49 , no. 4 , p. $883-896$

BOTELHO, ERO., SANTOS, MCF. and SOUZA, JRB., 2001. Aspectos populacionais do guaiamum, Cardisoma guanhumi Latreille, 1825, do estuário do rio Una (Pernambuco - Brasil). Boletim Técnico Científico do CEPENE, vol. 9, no. 1, p. 123-146.

$<$ jm>BOTELHO, ERO., SANTOS, MCF., ALMEIDA, L., SILVA, CGM. 2009. Caracterização biológica do guaiamum, Cardisoma guanhumi, Latreille, 1825 (DECAPODA: GECARCINIDAE) do estuário do rio Caravelas (CARAVELAS - BAHIA). Boletim Técnico-Científico do CEPENE, vol. 17, no. 1, p. 65-75.<1 jm $><$ bok $>$ BOZADA, L. and CHÁVEZ, Z., 1986. La fauna acuatica de la Laguna del Ostión. México: Centro de EcodesarrolloUniversidad Veracruzana. 131 p. vol. 2.

BRANCO, JO., 1991. Aspectos ecológicos dos brachyura (Crustácea: Decapoda) no manguezal do Itacorubi, SC - Brasil. Revista Brasileira de Zoologia, vol. 7, no. 1-2, p. 165-179.

Brasil. Instituto Brasileiro do Meio Ambiente e dos Recursos Naturais - IBAMA, 2003. Portaria $n^{\circ} 53$, de 30 de setembro de 2003. Diário Oficial da República Federativa do Brasil, Brasília, 02 out. Seção 1, p. 124.

BURGGREN, WW. and MCMAHON, BR. (Eds.), 1988. Biology of the land crabs. Cambridge: Cambridge University Press. 479 p. http://dx.doi.org/10.1017/CBO9780511753428.

DIAZ, H. and CONDE, JE., 1989. Populations dynamics and life history of the mangrove crab Aratus pisonii (Brachyura: Grapsidae) in a marine environment. Bulletin of Marine Science, vol. 45 , no. 1 , p. $148-163$

DIELE, K., KOCH, V. and SAINT-PAUL, U., 2005. Population structure, catch composition and CPUE of the artisanally harvested mangrove crab Ucides cordatus (Ocypodidae) in the Caeté estuary, North Brazil: Indications for overfishing? Aquatic Living Resources, vol. 18, no. 2, p. 169-178. http://dx.doi.org/10.1051/alr:2005018.

DIELE, K. and KOCH, V., 2010. Growth and mortality of the exploited mangrove crab Ucides cordatus (Ucididae) in N-Brazil. Journal of Experimental Marine Biology and Ecology, vol. 395, no. 1-2, p. 171-180. http://dx.doi.org/10.1016/j.jembe.2010.08.029.

D'INCAO, F., RUFFINO, ML., DA SILVA, KG., BRAGA, AC. and MARQUES, LHC., 1993. Crescimento de Chasmagnathus granulata Dana, 1851, em um marisma do estuário da Lagoa dos Patos, RS (Decapoda: Grapsidae). Revista Brasileira de Biologia = Brazilian Journal of Biology, vol. 53, no. 4, p. 637-643.

DUARTE, MS., MAIA-LIMA, FA. and MOLINA, WF., 2008. Interpopulational morphological analyses and fluctuating asymmetry in the brackish crab Cardisoma guanhumi Latreille (Decapoda, Gecarcinidae), on the Brazilian Northeast coastline. Pan-American Journal of Aquatic Science, vol. 3, no. 3, p. 294-303.

FELICIANO, C., 1962. Notes on the biology and economic importance of the land crab Cardisoma guanhumi Latreille of Puerto Rico. Porto Rico: University of Puerto Rico. p. 1-13. Special Contribution, Institute of Marine Biology.

FIRMO, AMS., TOGNELLA, MMP., SILVA, SR., BARBOZA, RRRD. and ALVES, RRN., 2012. Capture and commercialization of blue land crabs ("guaiamum") Cardisoma guanhumi (Latreille, 1825 ) along the coast of Bahia State, Brazil: an ethnoecological approach. Journal of Ethnobiology and Ethnomedicine, vol. 8, no. 12 , p. $2-12$

FISCHER, W., SERVICE, MR. and RESOURCES, F., 1978. FAO species identifications sheets for fishery purposes. Rome: Food and Agriculture Organization of the United Nations. p. 94-124.

FISCHER, W., THATJE, S. and BREY, T., 2009a. Early egg traits in Cancer setosus (Decapoda, Brachyura): effects of temperature and female size. Marine Ecology Progress Series, vol. 377, p. 193-202. http://dx.doi.org/10.3354/meps07845.

FISCHER, W., THATJE, S., GRAEVE, M., PASCHKE, K. and KATTNER, G., 2009b. Bioenergetics of early life-history stages of the brachyuran crab Cancer setosus in response to changes 
in temperature. Journal of Experimental Marine Biology and Ecology, vol. 374, no. 2, p. 160-166. http://dx.doi.org/10.1016/j. jembe.2009.04.019.

FISHER, RA., 1930. The genetical theory of natural selection. Oxford: Clarendon. $272 \mathrm{p}$.

GAYANILO, FCJR., SPARRE, P. and PAULY, D., 1996. The FAO-ICLARM stock assessment tools (FISAT). User's guide. Rome: Food and Agriculture Organization of the United Nations. p. 1-186. FAO Computerized Information Series - Fisheries, no. 6.

GAYANILO, FCJR. and PAULY, D., 1997. FAO-ICLARM stock assessment tools (FISAT). Reference manual. Rome: Food and Agriculture Organization of the United Nations. p. 1-262. FAO Computerized Information Series - Fisheries, no. 8.

GIFFORD, CA., 1962. Some observations on the general biology of the land crab, Cardisoma guanhumi (Latreille), in South Florida. The Biological Bulletin, vol. 123, no. 1, p. 207-223. http://dx.doi. org/10.2307/1539516.

GIL, LS., 2009. Aspectos biológicos do caranguejo Cardisoma guanhumi - (Latreille, 1825) (Decapoda, Brachyura, Gecarcinidae) no núcleo de Picinguaba do Parque Estadual da Serra do Mar, litoral do Estado de São Paulo, Brasil. São Paulo: Instituto de Pesca. 45 p. Dissertação de mestrado em Aquicultura e Pesca.

GIMENEZ, E. and ACEVEDO, M., 1991. Relaciones morfométricas y talla de primeira maduración del cangrejo de tierra Cardisoma guanhumi Latreille en la cienaga de zapata. Revista Cubana de Investigaciones Pesqueras, vol. 7, no. 3, p. 18-37.

GLEENSON, RA., 1991. Intrinsic factors mediating pheromone communication in the blue crab, Callinectes sapidus. In BAUER, RT. and MARTIN, JW. (Eds.). Crustacean sexual biology. New York: Columbia University Press. p. 17-32.

HARTNOLL, RG., 1982. Growth. In ABELE, LG. (Ed.). The biology of Crustacea. New York: Academic Press. p. 111-196.

HARTNOLL, RG., 2006. Reproductive investment in Brachyura. Hydrobiologia, vol. 557, no. 1, p. 31-40. http://dx.doi.org/10.1007/ s10750-005-9305-6.

HARTNOLL, RG., 2009. Sexual maturity and reproductive strategy of the rock crab Grapsus adscensionis (Osbeck, 1765) (Brachyura, Grapsidae) on Ascension Island. Crustaceana: International Journal of Crustacean Research, vol. 82, no. 3, p. 275-291. http://dx.doi.org/10.1163/156854009X409090.

HENNING, HG., 1975. Ökologische, ethologische und sinnesphysiologische untersuchungen an der landkrabbe Cardisoma guanhumi Latreille (Decapoda, Brachyura). Forma et Functio, vol. 8 , p. 253-304.

HERREID, CF., 1967. Skeletal meansurements and growth of the land crab Cardisoma guanhuni Latreille. Crustaceana, vol. 13, no. 1, p. 39-44. http://dx.doi.org/10.1163/156854067X00053.

HILL, K., 2001. Cardisoma guanhumi [Internet]. Smithsonian Marine Station at Fort Pierce. Available from: $<$ http://www.sms. si.edu/IRLSpec/Cardis_guanhu.htm>. Access in: 22 Oct. 2009.

HINES, AH., 1989. Geographic variation in size at maturity in brachyuran crabs. Bulletin of Marine Science, vol. 42, no. 2, p. 356-368.

JOHNSON, PTJ., 2003. Biased sex ratios in fiddler crabs (Brachyura, Ocypodidae): A review and evaluation of the influences of sampling method, size class, and sex specific mortality. Crustaceana, vol. 76, no. 5, p. 559-580. http://dx.doi. org/10.1163/156854003322316209.
LITULO, C., 2005. Population biology of the fiddler crab Uca annulipes (Brachyura: Ocypodidae) in a tropical East African mangrove (Mozambique). Estuarine, Coastal and Shelf Science, vol. 62, no. 1-2, p. 283-290. http://dx.doi.org/10.1016/j. ecss.2004.09.009.

LUPPI, TA., SPIVAK, ED., BAS, CC. and ANGER, K., 2004. Molt and growth of an estuarine crab, Chasmagnathus granulatus (Brachyura: Varunidae), in Mar Chiquita coastal lagoon, Argentina. Journal of Applied Ichthyology, vol. 20, no. 5, p. 333-344. http:// dx.doi.org/10.1111/j.1439-0426.2004.00575.x.

MELO, GAS., 1996. Manual de identificação dos Brachyura (caranguejos e siris) do litoral Brasileiro. São Paulo: Plêiade/ FAPESP. 603 p.

MÜLLER, YMR., NAZARI, EM., AMMAR, D., CARGNIN FERREIRA, E., BELTRAME, IT. and PACHECO, C., 1999. Biologia dos Palaemonidae (Crustacea, Decapoda) da bacia hidrográfica de Ratones, Florianópolis, Santa Catarina, Brasil. Revista Brasileira de Zoologia, vol. 16, no. 3, p. 629-636. http:// dx.doi.org/10.1590/S0101-81751999000300004.

DE OLIVEIRA-NETO, JF., PIE, MR., CHAMMAS, MA., OSTRENSKY, A. and BOEGER, WA., 2008. Phylogeography of the blue land crab, Cardisoma guanhumi (Decapoda: Gecarcinidae) along the Brazilian coast. Journal of the Marine Biological Association of the United Kingdom, vol. 88, no. 7, p. 1417-1423. http://dx.doi.org/10.1017/S0025315408001999.

OSHIRO, LMY., SILVA, R. and SILVEIRA, CM., 1999. Rendimento de carne nos caranguejos guaiá, Menippe nodifrons Stimpson, 1859 e guaiamum, Cardisoma guanhumi Latreille, 1825 (Crustacea, Decapoda, Brachyura) da Baía de Sepetiba/RJ. Acta Biologica Leopoldinensia, vol. 21, no. I, p. 83-88.

PALOMARES, MLD. and PAULY, D., 2009. The growth of jellyfishes. Hydrobiologia, vol. 616, no. 1, p. 11-21. http://dx.doi. org/10.1007/s10750-008-9582-y.

PAULY, D., 1986. On improving operation and use of the ELEFAN programs. Pt. II. Improving the estimation of Linf. Fishbyte, vol. 4, no. 1 , p. $18-20$.

PAULY, D. and DAVID, N., 1981. ELEFAN I, a BASIC program for the objective extraction of growth parameters from lengthfrequency data. Meeresforschung, vol. 28, no. 4, p. 205-211.

REID, DG., ABELLO, P., KAISER, MJ. and WARMAN, CG., 1997. Carapace color, inter-molt duration and the behavioral and physiological ecology of the shore crab Carcinus maenas. Estuarine, Coastal and Shelf Science, vol. 44, no. 2, p. 203-211. http://dx.doi.org/10.1006/ecss.1996.0212.

REUSCHEL, S. and SCHUBART, CD., 2007. Contrasting genetic diversity with phenotypic diversity in coloration and size in Xantho poressa (Brachyura: Xanthidae), with new results on its ecology. Marine Ecology (Berlin), vol. 28, no. 2, p. 296-305. http://dx.doi. org/10.1111/j.1439-0485.2006.00139.x.

RIVERA, JJ., 2005. El cangrejo terrestre C. guanhumi: un recurso pesquero? Ecofronteiras, vol. 25, p. 15-17.

RODRÍGUEZ-FOURQUET, C. and SABAT, AM., 2009. Effect of harvesting, vegetation structure and composition on the abundance and demography of the land crab Cardisoma guanhumi in Puerto Rico. Wetlands Ecology and Management, vol. 17, no. 6, p. 627640. http://dx.doi.org/10.1007/s11273-009-9139-5.

SCHAEFFER-NOVELLI, Y., 1989. Perfil dos ecossistemas litorâneos brasileiros, com especial ênfase sobre o ecossistema 
manguezal. Publicação Especial do Instituto Oceanográfico São Paulo, vol. 7, p. 1-16.

SHINOZAKI-MENDES, RA., 2008. Biologia reprodutiva do guaiamum, Cardisoma guanhumi Latreille, 1828 (Decapoda: Gecarcinidae) na Região de Aracati, CE. Pernambuco: Universidade Federal Rural de Pernambuco. 90 p. Dissertação de Mestrado em Recursos Pesqueiros e Aquicultura.

SHINOZAKI-MENDES, RA., SANTANDER-NETO, J., SILVA, JRF. and HAZIN, FHV., 2008. Sazonalidade da Proporção Sexual do Guaiamum, Cardisoma guanhumi LATREILLE, 1828 (Decapoda: Gecarcinidae) no Estuário do Rio Jaguaribe, Ceará. Revista Brasileira de Engenharia de Pesca, vol. 3, no. 3, p. 27-30.

SHINOZAKI-MENDES, RA., SILVA, JRF., SOUSA, LP. and HAZIN, FHV., 2012a. Histochemical study of the ovarian development of the blue land crab Cardisoma guanhumi (Crustacea: Gecarcinidae). Invertebrate Reproduction \& Development, vol. 56 , no. 3, p. 191-199.

SHINOZAKI-MENDES, RA., SILVA, JRF. and HAZIN, FHV., 2012b. Development of male reproductive system of the blue land crab Cardisoma guanhumi Latreille, 1828. (Decapoda: Gecarcinidae). Acta Zoologica, vol. 93, no. 4, p. 390-399. http:// dx.doi.org/10.1111/j.1463-6395.2011.00513.x.

SILBIGER, N. and MUNGUIA, P., 2008. Carapace color change in Uca pugilator as a response to temperature. Journal of Experimental Marine Biology and Ecology, vol. 355, no. 1, p. 41-46. http://dx.doi.org/10.1016/j.jembe.2007.11.014.

SILVA, R. and OSHIRO, LMY., 2002. Aspectos da reprodução do caranguejo guaiamum Cardisoma guanhumi (Latreille) (Crustacea, Decapoda, Gecarcinidae) da Baía de Sepetiba, Rio de Janeiro, Brasil. Revista Brasileira de Zoologia, vol. 19, no. 1, p. 71-78. http://dx.doi.org/10.1590/S0101-81752002000600007.

SUBIRÁ, RJ., SOUZA, ECF., GUIDORIZZI, CE., ALMEIDA, MP., ALMEIDA, JB. and MARTINS, DS., 2012. Avaliação científica do risco de extinção da fauna brasileira - Resultados alcançados em 2012. Biodiversidade Brasileira, vol. 2, no. 2, p. 17-24.

TAISSOUN, E., 1974. El cangrejo de tierra Cardisoma guanhumi (Latreille) en Venezuela. Boletín Centro de Investigaciones Biologicas, vol. 10, p. 9-41.
TODD, PA., BRIERS, RA., LADLE, RJ. and MIDDLETON, F., 2006. Phenotype-environment matching in the shore crab (Carcinus maenas). Marine Biology, vol. 148, no. 6, p. 1357-1367. http:// dx.doi.org/10.1007/s00227-005-0159-2.

VANNUCCI, M., 1999. Os manguezais e nós: uma síntese de percepções. São Paulo: Edusp. 233 p.

VAZZOLER, AEAM., 1996. Biologia da reprodução de peixes teleósteos: teoria e prática. Maringa: Nupelia. 169 p.

WARNER, GF., 1967. The life history of the mangrove tree crab Aratus pisonii. Journal of Zoology, vol. 153, no. 3, p. 321-335. http://dx.doi.org/10.1111/j.1469-7998.1967.tb04066.x.

WEDES, S., 2004. Cardisoma guanhumi [Internet]. Animal Diversity Web. Available from: $<$ http://animaldiversity.ummz. umich.edu/site/accounts/information/Cardisoma_guanhumi. html>. Access in: 22 Nov. 2011.

WENNER, AM., 1972. Sex ratio as a function of size in Marine Crustacea. American Naturalist, vol. 106, no. 949, p. 321-350. http://dx.doi.org/10.1086/282774.

WETHERALL, JA., 1986. A new method for estimating growth and mortality parameters from length-frequency data. Fishbyte, vol. 4 , no. 1 , p. 12-14

WETHERALL, JA., POLOVINA, JJ. and RALSTON, S., 1987. Estimating growth and mortality in steady-state fish stocks from length frequency data. In PAULY, D. and MORGAN, GR. (Eds.). Length-based methods in fisheries research. Manila: International Center for Living Aquatic Resources Management/Safat: Kuwait Institute for Scientific Research. p. 53-74. ICLARM Conference Proceedings, no. 13

WOLCOTT, TG., 1988. Ecology. In BURGGREN, WW. and MCMAHON, BR., (Eds.). Biology of the land crabs. New York: Cambridge Press. p. 55-96. http://dx.doi.org/10.1017/ CBO9780511753428.004.

ZAR, JH., 1999. Biostatistical analysis. New Jersey: Prentice Hall. 663 p. 